myself the task to prove) there is not really more than one explanation of the constitution of the ether in principle conceivable [excluding, of course, the essentially endless vagaries about "forces"], then on this ground alone the hope may be entertained by those who look to the existence of an explanation for every physical fact, that difficulties that may naturally present themselves at first will not prove insurmountable by a due amount of thought and careful analysis.

S. Tolver Preston

\section{The Transverse Vibrations of Light}

FEW are probably likely to underrate the vast benefits which have accrued to physical science since the time of Poisson, from the application of mathematical analysis to physical problems; but it seems to me we are at present rather in danger of forgetting that such mathematical reasoning can only lead to useful results when founded upon definite physical conceptions. It was upon such a basis that the triumphs of Young, Fresnel, and Airy were won; and it is for want of such a basis that I fear we shall get little aid from Mr. Tolver Preston's ingenious speculation, Mr. Hicks has taken some exceptions to them, which seem sound if he has correctly read the theory, though I am not quite sure he has, or that $\mathrm{I}$ should go quite with him in regard to what $\mathrm{Mr}$. Preston may mean. But I wish to point out, with your permis sion, objections of a more simple and definite physical nature.

The only transverse movements capable of being communicated to an ether-molecule by transverse vibrations of matter, which do not involve translation through a measurable though minute distance in space, appear to be rotation on an axis, or (if we conceive the molecule as an annulus) alternate contraction and expansion-" vibration" Mr. Preston calls it-within its own limits. In the case of a gaseous constitution, transverse translation in space with the assumed long free path, must continue, and result in a free path different from the assumed direction of the ray. The particles of sand employed to illustrate the subject thus acquire a continusus transverse motion in passing through the sieve, and do not "vibrate" or come back in an orbit. Such true vibratory motion is the main characteristic of solid bodies, and is the best known reason for conceiving the ether as of a "solid" constitution.

What I wish to point out is, that large classes of phenomena appear to demand such actual transverse motion in orbits of the entire ether particles, and cannot at present be explained without. I confine myself to two of the simplest examples from polarisation. It is well known that the production of complementary colours from a plane polarised ray by a doubly-refracting film and analyser, may be simply represented to the eye and the mind by the following diagram equation, which shows the resolution of actual motions.

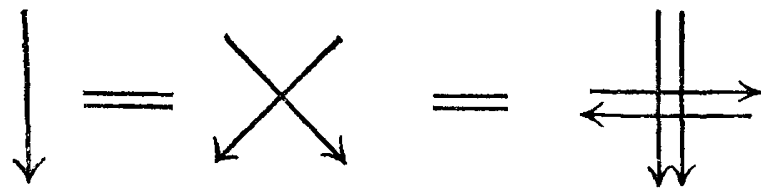

Similarly, the two circularly-polarised rays in quartz, and their conversion on emergence into a plane ray rotated on its axis by the angular value of the difference in velocity, may be represented thus :-

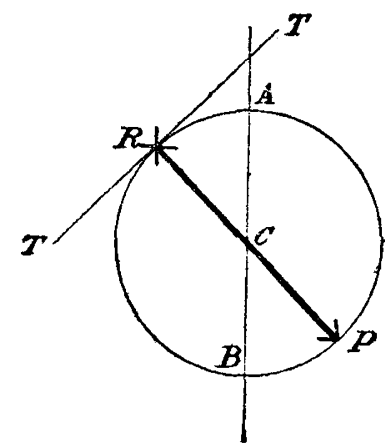

Here actual motions in the plane $A B$ are resolved into two opposite circular motions represented by the doubly-barbed circle, which meet on their emergence at the point $\mathrm{R}$, to which their respective velocities from the common departure $A$ have brought them. There they are again resolved, the two tangential forces $T R$ destroying each other, and the two radial forces, $\mathrm{R} C$, uniting in the rotated plane wave, $R P$. Here again we have throughout actual motions, through definite distances. And I am at a loss to see how whole classes of phenomena of which these are typical can be explained in any other way, or by any but a true "vibration" bodily to and fro in space. If it be so, then it is not enough for some vague physico-mathematical notion to satisfy abstract mathematical conditions; we must ask for the definite physical conception which is to accou at for the physical phenomena. Until we have this we have made no real advance in comprehending the physics of the ether.

At the same time I cordially arree with Mr. Preston in his regret at the comparative distaste for the study of this subject; and I may, perhaps, add a suggestion on my own part, though not really new. To my own mind it seems as easy to conceive of "matter" without gravity as with it, and of infinite elasticity as of elasticity at all (which is not easy). In ponderable matter, again, the most bighly elastic solid bodies are as "solid" as the least; the greater mobility of their atoms by no means interferes with that peculiarity of vibrating in orbits and preserving a locus which distinguishes solids from fluids, and which so far we have been obliged by the phenomena to attribute to the ether also. Granted that to account for elasticity we have to conceive atoms not in contact, and are confronted by the old mystery of how they can act upon each other across a vacuum. Still, does this confront us any more in the ether than in ponderable matter ; and, so far as they do go, are not our conceptions of the one sufficient for and equally applicable to the other?

Wellfield, Ashley Road, Crouch Hill, N.

LEWIS WRIGHT

\section{Diffusion of Copper in the Animal Kingdom}

JE lis dans la NATURE, vol. xxi. p. 305, un article intitulé "Diffusion of Copper in the Animal Kingdom,"se terminant par ces mots: it is to be hoped that more extended observations woill inform us of the exact nature of the role played by cupric compounds in the animal economy. Je crois pouvoir satisfaire en partie au moins à ce vœu. Dans plusieurs communications insérées dans les publications des Académies des Sciences de Paris et de Bruxelles (1878 et $\mathbf{1} 879$ ), j'ai montré que chez certains mollusques céphalopodes et gastéropodes et chez les crustacés décapodes, le cuivre joue dans le sang le même rôle physiologique que le fer dans notre sang.

Le sang veineux du poulpe (Octopus vulgaris), du homard (Homaru,), etc., contient ane substance albuminoide incolore, cuprifère, à laquelle j'ai donné le nom d'hémocyanine, terme rappelant sa parenté avec l'hémoglobine. L'hémocyanine forme dans la branchie une combinai on peu stable avec l'oxygène ; cette combinaison l'oxy-hémocy'anine est d'un beau bleu. Elle se décolore en se dissociant sous l influence du vide ou du contact avec les tissus vivants. Aussi le sang artériel du poulpe est d'un beau bleu tant que l'animal respire une eau bien aérée. Il suffit de comprimer la branchie, de gêner la respiration, pour voir le sang artériel se décolorer.

L'hémocyanine parâ̂t avoir une constitution chimique analogue à celle de l'hémoglobine. Comme cette dernière elle est susceptible de se dédoubler en une substance albuminoide ne contenant pas de métal et en une substance cuprifère qui paraît former des sels cristallisables analogues aux sels d'hématine.

Liége, le II février, sue du parc, 25

LÉON FREDERICQ

\section{Lines of Force due to a Small Magnet}

I HAVE been recommended by Sir William Thomson to send you the following construction for the lines of force due to a very small magnet.

The equation to the lines of force due to a very small magnet placed at the origin of co-ordinates and lying along the axis of $\boldsymbol{x}$ is -

$$
\frac{y^{2}}{\left(x^{2}+y^{2}\right)^{\frac{3}{2}}}=\frac{\mathrm{I}}{C} \cdot \text {. . . . . . . . }
$$

By varying $C$ we obtain a series of similar curves.

Transforming to polar co-ordinates by putting $x=r \cos \theta$, $y=r \sin \theta$, we get for the equation ( $x$ )

$$
r=C \sin ^{2} \theta \text {. }
$$

